exact measurements, which I am sorry for, as the cobra in question measured 6 feet 3 inches in length, a size Col. $R$. Beddome-no mean authority-assured me is seldom or never surpassed.

In a work such as Dr. Brehm's, exaggerations in illustrations should be as carefully avoided as misstatements in letterpress. A Natural History that depicted horses the size of elephants would be scoffed at, yet, strange to say, equally glaring absurdities, such as "cobra charming," frequently pass muster.

Bath, September Io

E. H. PRINGLE

\section{The Sea-Serpent Explained}

If you have space for the following, it is so confirmatory of Dr. Drew's experience of an opera.glass dispelling "fond deceits" concerning a sea-serpent, that it may be worth recording.

One morning in October, 1869 , I was standing amid a small group of passengers on the deck of the ill-fated P. and $O$. ss. Rangoon, then steaming up the Straits of Malacca to Singapore. We were just within sight of the coast of Malacca, and quite out of sight, so far as I remember, of Sumatra. One of the party suddenly pointed out an object on the port bow, perhaps half a mile off, and drew from us the simultaneous exclamation of "The sea-serpent!" And there it was, to the naked eye, a genuine serpent, speeding through the sea, with its head raised on a slender curved neck, now almost buried in the water, and anon reared just above its surface. There was the mane, and there were the well-known undulating coils stretching yards behind.

But for an opera-glass, probably all our party on board the Rangoon would have been personal witnesses to the existence of a great sea-serpent, but, alas for romance! one glance through the lenses and the reptile was resolved into a bamboo, root upwards, anchored in some manner to the bottom-a "snag," in fact. Swayed up and down by the rapid current, a series of waves undulated beyond it, bearing on their crests dark-coloured weeds or grass that had been caught by the bamboo stem.

Ignorance of the shallowness of the straits so far from land, and of the swiftness of the current, no doubt led us to our first hasty conclusion, but the story, with Dr. Drew's, shows how prone the human mind is to accept the marvellous, and how careful we should be in forming judgments even on the evidence of our senses.

Batb, September Io

E. H. PRINGLE

Dr. Drew's letter in Nature, vol, xviii. p. 489 , recalls to my mind a similar phenomenon witnessed by myself and a friend on August 3, while crossing from Grimsby to Rotterdam. It was towards evening, when, looking ahead, we saw, about a mile distant, what appeared to be a long, low, black hull, without masts or funnel, moving through the water at enormous speed. After a minute or two it undulated and rose from the surface, and we saw that it was a flight of birds.

The deception was so complete that I can well believe that at least many of the stories of the sea-serpent have so originated, though $I$ doubt whether all can be explained in this manner.

Grammar School, Bradford, September 7 C. BIRD

THE communication of Dr. Joseph Drew in your issue of yesterday regarding the serpentine appearance of a flock of shags in the English Channel is extremely interesting even as a mere fact regarding the habits of these birds. Will you kindly permit me, however, to point out that Dr. Drew's statement cannot be regarded as explanatory of the sea-serpent's personality? At the most the incident only explains one of a number of serpentine appearances of which porpoises and sunfishes swimming in line, pieces of wood with trains of sea-weed, \&c., are also good examples. There have been placed on record numerons incidents of serpentine forms having been closely in. spected (as in the well-known case of the Daedulus, or later still of H.M.S. Osborne) where the hypothesis of the serpentine appearances assumed by flocks of birds or fishes conld not be held as explanatory in any sense. It is with the view of showing that the exact personality of the "sea-serpent" cannot be accounted for by such an incident as Dr. Drew relates, that I venture to pen these remarks; and as a firm believer from the standpoint of zoology that the large development of the marine ophidians of warm seas offers the true explanation of the "sea-serpent" mystery, I would also ask your readers to distinguish carefully between cases in which serpentine appearances have been assumed by ordinary animals, and those in which one animal form has presented itself in the guise of the "great unknown." I am far from contending that a sea-snake developed in the ratio of a giant "cuttle-fish," presents the only solition of this interesting problem. A long tape-fish, or even a basking shark of huge dimensions, might do duty in the eyes of non-zoological observers for a "sea-serpent." The following cutting from the Scotsman of September 6, indeed, seems explicable only on the tape-fish theory which $I$ have advocated with the persistence of firm belief within the past few years. At the same time zoologists cannot but feel indebted to Dr. Drew, and to those who, like that gentleman, note unwonted appearances in ordinary animal life, and communicate such incidents to your columns.

Edinburgh School of Medicine, September 6

The following is the extract alluded to:-

"A Baby Sea-Serpent.-From Van Diemen's Land comes news of the capture of a queer fish. . It is fourteen feet long, fifteen inches deep from the neck to the belly, tapering two inches to the tail, and eight inches in diameter in the thickest place. There are no scales, but the skin is like polished silver, with eighteen clark lines and rows of spots running from the head to the tail each side. There is a mane on the neck twenty inches long, and continues from the head to the tail; small head, no teeth, protrusive mouth, capable of being extended four inches like a sucker; eyes flat abont the size of a halfcrown, and like silver, with black pupils. There are two feelers under the chin, thirty-two inches long. The fish was alive when captured."

\section{Alpine Flowers}

IN the Alps I have found some instances of different forms of flozvers in plants of the same species, which, as far as I know, have been hitherto undescribed, and of which, therefore, I will give a short notice here.

Geranium sylvaticum is in one locality near the Albula Pass gynodiacious, with large-flowered hermaphrodite, and smallflowered female stems. Veratrum album, Dryas cotopetala, and Geum reptans, are in all the localities where I have examined them, androdiocious. Astrantia minor offers a quite peculiar sort of androdiocism, some stems bearing, as in other Umbelliferæ, in the same umbel hermaphrodite flowers and male ones, other stems producing solely male flowers. Dianthus superbus seems at first sight to exist in three forms: (I) stems with hermaphrodite flowers, being perfectiy proterandrous and producing a moderate quantity of whitish pollen; (2) stems with female flowers containing very conspicuous rudiments of stamens but pollenless anthers; (3) stems with pistils remaining imperfectly developed and with anthers containing abundance of a brown powder. At first sight I thought their flowers to be male, and the brown powder to be pollen grains, but under the microscope the latter proved to consist of grains, the diameter of which is only about one-eighth of that of the pollen grains of the hermaphrodite flowers. I suppose, therefore, these grains to be the spores of some species of fungus, and Dianthus superbus to be gynodiacious.

Berninahaus, August 29

HermanN" MÜller

\section{The Microphone}

WHILE studying the relation between the battery power and the sounds heard through the microphone, I found, when the latter was included in the circuit between two pairs of elements, that the sound first amplified by the microphone underwent further amplification by the action of the second pair of elements, and when heard through the telephone the volume of sound was considerably augmented. This new fact may perhaps open up a fresh avemne of research and lead to further development of Prof. Hughes' beautiful discovery. Hull

THONIAS ROWNEY ingerts

\section{A Meteor}

WHILE directing a small telescope towards Jupiter, at 9.35 P.M. on the and inst., my attention was attracted by the bright light of what proved to be a large meteor, falling towards the southwestern horizon. Its apparent size was two or three times that 